IVANA HANZEC MARKOVIĆ

Sveučilište u Zagrebu - Hrvatski studiji

Odsjek za psihologiju

ihanzec@hrstud.hr
Primljeno: 09. 10. 2019.

Prihvaćeno: 16. 10. 2019.

DOI: $10.21857 /$ ygjwrcje7y

\title{
RANA ŠKOLSKA PRILAGODBA KAO POKAZATELJ DJEČJE DOBROBITI: PREDIKTIVNA VAŽNOST INDIVIDUALNIH KARAKTERISTIKA DJETETA
}

Dječja (školska) dobrobit odnosi se na dobre osjećaje i učinkovito funkcioniranje u školskom kontekstu, što je u psihologiji obrazovanja obuhvaćeno pojmom školske prilagodbe. Rana prilagodba posebno je važna zbog povezanosti s budućom prilagodbom i obrazovnim napretkom učenika/ ica, zbog čega je cilj ovog istraživanja bio ispitati ulogu socijalno-emocionalne kompetencije i specifičnih kognitivnih sposobnost djeteta u predikciji rane socijalne i akademske prilagodbe na školu, te ispitati moguću moderatorsku ulogu spola u tom odnosu. Rezultati su pokazali da su specifične kognitivne sposobnosti važnije za predikciju različitih pokazatelja rane školske prilagodbe nego socijalno-emocionalna kompetencija, te da spol ne moderira promatrane odnose.

\section{UVOD}

Dječja dobrobit vrlo je često istraživan konstrukt o kojemu se puno govori i piše, ne samo u znanstvenim krugovima, već i u svakodnevnom životu. Različiti autori pod tim pojmom podrazumijevaju vrlo različite stvari, istražujući jedan ili više pokazatelja dobrobiti, njihove prediktore i/ili ishode. Općeprihvaćeno jest 
IVANA HANZEC MARKOVIĆ: Rana školska prilagodba kao pokazatelj dječje dobrobiti: prediktivna važnost ...

da se radi o višedimenzionalnom konstruktu, koji se, općenito govoreći, odnosi na optimalno funkcioniranje i iskustvo djeteta, uključujući i ostvarivanje prava i kvalitetu života, ali i rizike i nepovoljne ishode po dijete (Ajduković, 2015). Osim što su neki pokazatelji dječje dobrobiti pozitivni, a neki negativni, dijele se i na objektivne i subjektivne, a velik broj pojedinačnih pokazatelja ili indikatora obično se grupira u manji broj kategorija. Primjerice, za nacionalne indikatore dječje dobrobiti u Hrvatskoj definiran je skup od 9 kategorija (zdravlje, obrazovanje, obiteljski odnosi, subjektivna i psihološka dobrobit, materijalna dobrobit i siromaštvo, odnosi s vršnjacima i rizična ponašanja, sudjelovanje, sigurnost djece, ranjive skupine djece)(Unicef, 2017). S obzirom na količinu vremena koju djeca provode u školi (nekoliko sati dnevno, 5 dana u tjednu, većinu tjedana u godini, i tako barem 8 godina, budući da je osnovna škola obavezna za svu djecu u Hrvatskoj), ona predstavlja važno okruženje za razvoj njihove dobrobiti. Osim što stječu obrazovanje, djeca u školi rastu, razvijaju se i odgajaju u odnosima s učiteljima/cama i vršnjacima. Iz tog razloga, škola i obrazovanje važni su za njihovu dobrobit, a njihova prilagodba na školu ujedno predstavlja pokazatelj njihove (školske) dobrobiti (koliko se dobro osjećaju i koliko dobro/učinkovito funkcioniraju u školskom kontekstu).

Dobru prilagodbu djeteta na školu često se izjednačavalo s akademskim uspjehom, budući da su zahtjevi školskog konteksta prvenstveno akademski i uključuju svladavanje školskog gradiva (Ladd, 1989; 2003; Perry i Weinstein, 1998). Međutim, s obzirom na postojanje mnogih drugih zahtjeva unutar školskog konteksta kojima djeca moraju udovoljiti da bi se uspješno prilagodila, posebice na početku školovanja, takva se tradicionalna definicija školske prilagodbe pokazala ograničenom. Zahtjevi početnog školovanja uključuju i snalaženje u novom socijalnom okruženju u kojem se očekuje osamostaljivanje, preuzimanje odgovornosti za sebe i svoje stvari, reguliranje vlastitog ponašanja, emocija i pažnje, konformiranje očekivanjima učitelja/ice i školskim rutinama, pridruživanje novoj skupini vršnjaka i stvaranje prijateljstava i slično (Ladd, 1989; Patrick, Suk Yoon i Murphy, 1995; Perry i Weinstein, 1998). Iz tog je razloga definicija prilagodbe na školu u modelima i istraživanjima 90-ih godina prošlog stoljeća proširena i na neakademske, socijalne ili socijalno-emocionalne pokazatelje. Primjerice, Perry i Weinstein (1998) u svojoj konceptualizaciji školske prilagodbe uz akademsko navode i socijalno (odnosi s učiteljem/icom i vršnjacima) i ponašajno funkcioniranje (ponašanje u skladu s ulogom učenika i samoregulacija). Model rane školske prilagodbe Birch i Ladd (1996) obuhvaća pak pokazatelje prilagodbe poput dječje percepcije škole i školskog okruženja, afektivnog iskustva u školi te uključenosti i angažiranosti u razredu. 
Uspješna rana školska prilagodba važna je zbog dugoročnih posljedica, kako akademskih, zbog kumulativne prirode školskog gradiva i znanja koje se nadovezuje i nadograđuje na ono prvo stečeno (čitanje, pisanje, računanje), tako i socijalno-emocionalnih (osjećaji i slika o školi, o sebi, o drugima). Naime, istraživanja pokazuju kako je uspješnost udovoljavanja zahtjevima na početku školovanja povezana s budućim obrazovnim napretkom učenika/ica i općenito prilagodbom kasnije u životu (Alexander i Entwisle, 1988; Bowes, Harrison, Sweller, Taylor i Neilsen-Hewett, 2009). Iz tog razloga važno je istraživati odrednice ili prediktore rane prilagodbe. Da bi se djeca uspješno prilagodila na školu, važno je da raspolažu određenim sposobnostima i vještinama koje će im omogućiti lakše snalaženje u školskom kontekstu. Najčešće istraživane odrednice rane školske prilagodbe stoga su upravo individualne karakteristike djeteta. Za učinkovito funkcioniranje u školi i akademski uspjeh djeteta od neupitne su važnosti njegove/njezine kognitivne sposobnosti. U istraživanjima odrednica rane školske prilagodbe to je široko definirana kategorija koja uključuje vještine i sposobnosti poput općeg znanja, inteligencije, specifičnih kognitivnih sposobnosti, jezičnih vještina, pred-akademskih i ranih akademskih vještina poput razvoja pismenosti i računanja te perceptivno-motoričkih i motoričkih vještina (La Paro i Pianta, 2000; Tramontana, Hooper i Selzer, 1988). Iako heterogena, ova kategorija odražava tradicionalne definicije spremnosti za školu te uključuje vještine koje se smatraju nužnim preduvjetom za početno učenje čitanja, pisanja i računanja (Vlahović-Štetić, Vizek-Vidović, Arambašić i Miharija, 1995). Brojna istraživanja ispitala su prediktivnost jedne ili većeg broja vještina i sposobnosti iz kognitivne domene, mjerene u početku formalnog školovanja, te potvrdila njihovu važnost za akademski uspjeh i prilagodbu djeteta (npr. Bowes i sur., 2009; Downer i Pianta, 2006; Duncan i sur., 2007; LaParo i Pianta, 2000; Tramontana i sur., 1988). Međutim, njihova je prediktivnost za neakademske pokazatelje školske prilagodbe puno manje ispitivana.

lako su dječje kognitivne sposobnosti od neupitne važnosti za uspjeh u školi, neki autori navode da uspješna prilagodba na početku školovanja jednako, ako ne i više, zahtijeva socijalne i emocionalne kompetencije učenika/ica (Raver, 2002). U kontekstu ispitivanja važnosti tih kompetencija u obrazovnom okruženju često se koristi termin socijalno-emocionalnog učenja (eng. social-emotional learning, SEL) kako bi se naglasila mogućnost i važnost učenja vještina, stavova i vrijednosti ključnih za razvoj socijalno-emocionalne kompetencije pojedinca. U literaturi je identificirano pet skupina temeljnih, međusobno povezanih SEL kompetencija, a riječ je o samosvijesti, upravljanju sobom ili samokontroli, socijalnoj svijesti, socijalnim vještinama i odgovornom donošenju odluka (Zins, 
IVANA HANZEC MARKOVIĆ: Rana školska prilagodba kao pokazatelj dječje dobrobiti: prediktivna važnost ...

Bloodworth, Weissberg i Walberg, 2004). Dosadašnja istraživanja odnosa dječje socijalno-emocionalne kompetencije i školske prilagodbe i uspjeha usmjerila su se na različite aspekte socijalno-emocionalne kompetencije, a većina njih pokazala se prediktivnim za mnoge pokazatelje socijalne prilagodbe na školu. Primjerice, za kvalitetu odnosa koji djeca formiraju sa svojim učiteljima/cama važnim se pokazala samoregulacija (npr. Graziano, Reavis, Keane i Calkins, 2007; Silva i sur., 2011), te socijalne vještine i ponašanja koja djeca iskazuju na početku školske godine (Bowes i sur., 2009; Ladd i sur., 1999). Oba ova pokazatelja socijalno-emocionalne kompetencije pokazala su se važnima i za vršnjačko prihvaćanje (Ladd i sur.,1999; Ladd i Price, 1987; Trentacosta i Izard, 2007). Osim socijalnih ishoda, socijalno-emocionalna kompetencija ili neke njezine komponente pokazale su se važnima i za akademsku prilagodbu učenika/ica (Bossaert i sur., 2011; Downer i Pianta, 2006; Garner i Waajid, 2008; Graziano i sur., 2007; Trentacosta i Izard, 2007), izraženu procjenama učitelja/ica ili rezultatima učenika/ica na standardiziranim testovima. S druge strane, metaanaliza Duncana i suradnika (2007) pokazala je da različite mjere ranih socijalnoemocionalnih vještina i ponašanja uglavnom nisu značajni prediktori kasnijeg akademskog uspjeha, dok je u meta-analizi La Paro i Piante (2000) veličina učinka za predikciju socijalne prilagodbe na osnovu mjera socijalno-emocionalnog razvoja bila mala, objašnjavajući u prosjeku $10 \%$ varijabiliteta socijalnih školskih ishoda.

Jedna od individualnih karakteristika koja se često ispituje u istraživanjima školskog uspjeha i prilagodbe na školu je i spol djeteta. Međutim, nalazi o ulozi koju spol ima u objašnjenju rane školske prilagodbe nisu konzistentni. Kada je u pitanju akademska prilagodba, spol često nije njezin značajni prediktor (npr. Ladd i Dinella, 2009; Ladd, Kochenderfer i Coleman, 1996; Rhoades, Domitrovich i Greenberg, 2011), iako se u pregledima istraživanja navodi kao dosljedan nalaz da djevojčice postižu bolji akademski uspjeh tijekom cijelog školovanja u različitim državama, pa tako i u Hrvatskoj (Babarović, Burušić i Šakić, 2010; Burušić i Šerić, 2015). Odnos spola i različitih pokazatelja socijalne prilagodbe na školu nešto je konzistentniji. Istraživanja dosljedno pokazuju da djevojčice formiraju bliskiji odnos s učiteljima/cama (Birch i Ladd, 1997; Hughes i sur., 2008; Murray i Murray, 2004; Silva i sur., 2011) i prihvaćenije su među vršnjacima (Bossaert, Doumen, Buyse i Verschueren, 2011). Osim toga, djevojčice su više uključene u razredne aktivnosti (Betts i Rottenberg, 2007; Birch i Ladd, 1997; Ladd i Dinella, 2009), te češće imaju pozitivniji odnos prema školi (Birch i Ladd, 1997; Bowes i sur., 2009; Silva i sur., 2011), iako u nekim istraživanjima na tim mjerama nema značajnih razlika između djevojčica i dječaka (npr. Ladd i Dinella, 2009; Murray i 
sur., 2008). S obzirom na navedene razlike, neka istraživanja ispitivala su ulogu spola kao mogućeg moderatora u odnosu ranih vještina i kasnije školske prilagodbe i uspjeha. Rezultati pokazuju da ili nema dosljednog obrasca u smjeru djelovanja spola na odnose među ovim varijablama (Duncan i sur., 2007) ili da je za prilagodbu dječaka više nego za prilagodbu djevojčica važno da posjeduju odgovarajuće socijalno-emocionalne vještine i razviju kvalitetan odnos s učiteljem/ icom i vršnjacima (npr. Ladd i Price, 1987; Ladd i sur., 1996).

S obzirom na važnost školske prilagodbe kao pokazatelja dječje dobrobiti, dugoročne posljedice rane prilagodbe i nekonzistentne rezultate dosadašnjih istraživanja, cilj ovog istraživanja bio je ispitati i usporediti prediktivnu važnost socijalno-emocionalne kompetencije i specifičnih kognitivnih sposobnost za ranu prilagodbu djeteta na školu, te ispitati moguću moderatorsku ulogu spola u odnosu ovih individualnih karakteristika djeteta i rane školske prilagodbe. Pritom je školska prilagodba definirana u terminima akademskih, ali i socijalnih pokazatelja, a istovremenim ispitivanjem kognitivnih sposobnosti i socijalno-emocionalne kompetencije omogućeno je utvrđivanje njihova relativnog doprinosa. Očekuje se da će ove individualne karakteristike djeteta značajno doprinositi objašnjenju školske prilagodbe, pri čemu će socijalno-emocionalna kompetencija više doprinositi objašnjenju socijalne, a specifične kognitivne sposobnosti objašnjenju akademske prilagodbe djeteta.

\section{METODA}

\section{Sudionici}

U istraživanju je sudjelovalo ukupno 417 učenika/ica prvih razreda iz 12 osnovnih škola Grada Zagreba (202 djevojčice i 215 dječaka), prosječne dobi 7 godina na početku provođenja istraživanja $(M=7,12, S D=0,36)$. $U$ istraživanju su sudjelovali i njihovi roditelji, njih ukupno 372 (327 majki i 39 očeva, četvero roditelja je upitnike ispunjavalo zajedno, a dvoje ih nije navelo tko je ispunjavao) te učiteljice prvih razreda koje su učenici/e pohađali/e (34 učiteljice).

\section{Instrumenti}

Specifične kognitivne sposobnosti djece ispitane su Testom spremnosti za školu (TSŠ; Vlahović-Štetić i sur., 1995). TSŠ se sastoji od pet subtestova u boji kojima se ispituju grafomotorika, percepcija i znanje, tj. poznavanje činjenica (uključujući brojeve i aktivno baratanje njima). To su perceptivni test (TSŠ-P, 15 zadataka), test spajanja točaka (TSŠ-T, 10 zadataka), test poznavanja činjenica 
IVANA HANZEC MARKOVIĆ: Rana školska prilagodba kao pokazatelj dječje dobrobiti: prediktivna važnost ...

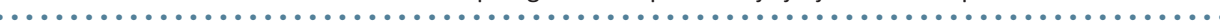

(TSŠ-Č, 14 zadataka), test precrtavanja (TSŠ-C, 9 zadataka) i numerički test (TSŠN, 10 zadataka). Testovi se rješavaju jedan po jedan, individualno ili u maloj grupi (u tom slučaju, uz grupno vođenje), u ukupnom trajanju od približno 45 minuta. Tri testa (TSŠ-P, TSŠ-Č i TSŠ-N) boduju se potpuno objektivno, prema ključu za odgovore, pri čemu točni odgovori nose 1 , a netočni 0 bodova. Zadaci u grafomotoričkim testovima (TSŠ-T i TSŠ-C) boduju se prema subjektivnim procjenama s 0 , 1 ili 2 boda, prema razrađenim uputama za bodovanje i primjerima navedenim u priručniku testa. U ovom istraživanju korelacije među subtestovima kreću se od 0,16 do 0,56, a Cronbachov alfa za TSŠ u cjelini iznosi 0,71. S obzirom na rezultate konfirmatorne faktorske analize, odlučeno je da će u obradi rezultata $u$ ovom istraživanju rezultati na pojedinim subtestovima biti korišteni kao indikatori latentnog konstrukta specifičnih kognitivnih sposobnosti.

Socijalno-emocionalna kompetencija djece mjerena je roditeljskim procjenama na 72 čestice Devereux procjene učeničkih snaga (DESSA; LeBuffe, Shapiro i Naglieri, 2009). Roditelji su procijenili i znakom „X“ označili učestalost opisanog ponašanja kod djeteta u protekla četiri tjedna, na skali od pet stupnjeva (od nikada do vrlo često, što se boduje s 0 do 4 boda). Čestice upitnika podijeljene su u osam skala - Samosvijest, Socijalna svijest, Samokontrola, Ponašanje usmjereno prema cilju, Socijalne vještine, Osobna odgovornost, Donošenje odluka i Optimistično mišljenje. Osim na pojedinačnim skalama, moguće je formirati i ukupni rezultat na temelju svih skala, koji predstavlja ukupni pokazatelj socijalno-emocionalne kompetencije djeteta, pri čemu viši rezultati ukazuju na višu kompetenciju djeteta. $U$ ovom istraživanju, kao rezultat provjere strukture upitnika konfirmatornim faktorskim analizama, odlučeno je da će pojedinačni rezultati na pet skala koje predstavljaju ključne SEL kompetencije (samosvijest, socijalna svijest, samokontrola, socijalne vještine i donošenje odluka) biti korišteni kao indikatori latentnog konstrukta socijalno-emocionalne kompetencije.

Rana školska prilagodba mjerena je većim brojem instrumenata:

Akademska prilagodba obuhvatila je četiri pokazatelja - rezultate učenika na ispitu znanja iz hrvatskog jezika, matematike i prirode i društva te ukupni rezultat na Skali akademske kompetencije.

Ispit znanja iz hrvatskog jezika, matematike i prirode i društva konstruiran je za potrebe ovog istraživanja, a sadržavao je pet zadataka iz hrvatskog jezika ( $\alpha$ $=0,67)$, osam zadataka iz matematike $(\alpha=0,69)$ te sedam zadataka iz prirode i društva $(\alpha=0,76)$. Učenici/e su rješavali ispit znanja cijeli školski sat. Zadaci su bodovani objektivno, prema unaprijed određenom ključu za bodovanje, a broj mogućih bodova razlikovao se u pojedinim zadacima te se kretao od 1 do 9 bo- 
dova po točno riješenom zadatku. Ukupni rezultat formiran je za svaki pojedinačni predmet, kao zbroj bodova u odgovarajućim zadacima.

Skala akademske kompetencije sadržavala je četiri čestice preuzete iz istoimene subskale instrumenta Sustav procjene socijalnih vještina (SSRS; Gresham i Elliott, 1990). Učiteljice su procijenile položaj svakog djeteta u odnosu na ostalu djecu u svom razredu, u čitanju, matematici, motivaciji za postignućem i ukupnoj akademskoj izvedbi, na skali od pet stupnjeva (od 1 - najnižih 10\%, do 5 - najviših 10\%). Ukupni rezultat formiran je kao prosjek odgovora na svim česticama skale, pri čemu veći rezultat odražava veću akademsku kompetenciju učenika. Pouzdanost skale u ovom istraživanju iznosi 0,93

Socijalna prilagodba obuhvatila je sljedeća četiri pokazatelja:

Odnos učenik-učitelj za svakog pojedinog učenika/icu procjenjivale su učiteljice na Kratkoj formi skale odnosa učenik-učitelj (STRS- Short Form; Pianta, 2001). Skala se sastoji od 15 čestica podijeljenih u dvije subskale, Bliskost (8 čestica, $\alpha=0,81$ ) i Konflikt (7 čestica, $\alpha=0,91$ ), koje učitelji/ce procjenjuju na Likertovoj skali od pet stupnjeva (od 1 - uopće ne, do 5 - u potpunosti da). Rezultat se može izražavati kao prosjek odgovora na pojedinoj subskali ili kao njihov kompozit, pri čemu veći ukupni rezultat na skali ukazuje na pozitivniji odnos učitelja/ ice s djetetom. Korelacija među subskalama u ovom istraživanju iznosi -0,48, a konfirmatorna faktorska analiza ukazala je na dobro pristajanje dvofaktorskog modela podacima, stoga je odlučeno da će u obradi rezultata u ovom istraživanju rezultati na subskalama biti korišteni kao indikatori latentnog konstrukta odnosa s učiteljicom.

Odnos s vršnjacima procjenjivali su sami učenici/e, na šest čestica subskale Socijalna prihvaćenost Profila samopercepcije za djecu (Harter, 1985) koja mjeri stupanj u kojemu su djeca uvjerena da su prihvaćena, popularna i da imaju prijatelje. Svaka čestica sadrži dvije povezane rečenice koje opisuju kompetentno, odnosno manje kompetentno dijete, a zadatak sudionika je najprije odabrati rečenicu koja ga bolje opisuje, a zatim znakom „X“ označiti opisuje li ga ta rečenica potpuno ili donekle točno. Rezultat se boduje na skali od četiri stupnja (1-najmanja kompetentnost, 4-najveća kompetentnost), a ukupni rezultat formira se kao zbroj odgovora na svim česticama skale, pri čemu veći rezultat znači veću socijalnu prihvaćenost. Dvije čestice u ovom istraživanju imale su vrlo niska zasićenja (niža od 0,20) na latentnom faktoru („Neka djeca željela bi imati puno više prijatelja./Druga djeca imaju onoliko prijatelja koliko god žele.“ i „Neka djeca željela bi se više sviđati drugoj djeci svojih godina./Druga djeca misle da se sviđaju većini djece svojih godina.") zbog čega su isključene iz daljnjih analiza te je odlu- 
čeno da će u obradi rezultata $u$ istraživanju biti korišten ukupni rezultat dobiven zbrajanjem rezultata na preostale četiri čestice skale $(\alpha=0,61)$.

Percepcija škole ispitana je procjenama učenika/ica na Upitniku sviđanja i izbjegavanja škole (SLAQ; Ladd i Price, 1987) koji ima 14 čestica podijeljenih u dvije subskale, Sviđanje škole (9 čestica, $\alpha=0,90$ ) i Izbjegavanje škole (5 čestica, $\alpha=0,79)$. Učenici/e odgovaraju na skali od tri stupnja, zaokruživanjem odgovora $d a$, ne ili ponekad koji se redom boduju s 2, 0 i 1 . Rezultat se može izražavati kao prosjek odgovora na pojedinoj subskali ili kao njihov kompozit, pri čemu veći ukupni rezultat odražava pozitivnu percepciju škole. S obzirom na visoku međusobnu korelaciju subskala $(r=-0,70)$ i dobro pristajanje jednofaktorskog modela podacima, u obradi rezultata u ovom istraživanju korišten je ukupni prosječni rezultat na upitniku koji ukazuje na sviđanje škole učenicima/cama $(\alpha=0,91)$.

Uključenost $u$ razredne aktivnosti je ispitana procjenama učiteljica na subskali Usmjerenost na zadatak u razredu (6 čestica, $\alpha=0,90$ ) koja je dio Kratke forme učiteljske skale procjene školske prilagodbe (Short-Form TRSSA; Betts i Rotenberg, 2007). Učiteljice na skali od tri stupnja (od 0 - uopće ne, do $2-u$ potpunosti) procjenjuju koliko se navedene tvrdnje odnose na pojedinog učenika/ icu u razredu. Rezultat se formira kao prosjek odgovora na česticama skale, a veći rezultat ukazuje na veću uključenost učenika/ica.

\section{Postupak}

Nakon dobivanja svih potrebnih dozvola (Etičkog povjerenstva za istraživanja s ljudima Odsjeka za psihologiju Filozofskog fakulteta u Zagrebu, Ministarstva znanosti, obrazovanja i sporta, ravnatelja/ica osnovnih škola i roditelja), podaci su prikupljani u dvije točke mjerenja - na početku i na kraju školske godine. U prvoj točki mjerenja, tijekom listopada/studenog, djeca su u školi, tijekom nešto više od jednog školskog sata, rješavala test specifičnih kognitivnih sposobnosti, grupno, uz vodstvo autorice ovog rada i pomoćnih istraživača/ica. Nakon rješavanja, djeci su podijeljene kuverte s upitnicima za roditelje koje su ponijeli kući, a roditelji su u pisanim obavijestima zamoljeni da priložene upitnike (o sociodemografskim podacima i socijalno-emocionalnoj kompetenciji njihove djece) ispune i u zatvorenoj kuverti vrate učiteljici svog djeteta u roku od tjedan dana. U drugoj točki mjerenja, tijekom svibnja/lipnja, procjenama učiteljica, samoprocjenama djece te ispitom znanja utvrđena je socijalna i akademska prilagodba djece na školu. Djeca su tijekom dva školska sata rješavala prvo upitnike o percepciji škole i odnosu s vršnjacima, a zatim ispit znanja, uz vodstvo autorice ovog rada i pomoćnih istraživača/ica. Učiteljice su dobile upitnike u kuvertama, i zamoljene 
su da ih u roku jednog do dva tjedna ispune i vrate u zatvorenoj kuverti školskom stručnom suradniku/ici.

\section{Postupci analize podataka}

Kako bismo ispitali i usporedili prediktivnu važnost socijalno-emocionalne kompetencije i specifičnih kognitivnih sposobnosti za socijalnu i akademsku prilagodbu na školu, proveli smo strukturalno modeliranje (eng. Structural Equation Modeling). Moderatorsku ulogu spola u postavljenom modelu provjerili smo multigrupnim testiranjem pristajanja modela, usporedbom dvaju ugniježdenih modela (bez i s ograničenjem jednakosti regresijskih koeficijenata između grupa).

S obzirom na nepotpunost uzorka na pojedinim varijablama, kao metoda procjene parametara korištena je MLR metoda (maximum likelihood estimation with robust standard errors). U svrhu provjere pristajanja modela podacima korišteni su relativni hi-kvadrat $\left(\chi^{2} / d f\right)$, RMSEA (Root Mean Square Error of Approximation), CFI (Comparative Fit Index), TLI (Tucker Lewis Index) i SRMR (Standardized Root Mean Square Residual). Vrijednosti $\chi^{2} / \mathrm{df}<3$, RMSEA < 0,06, CFI i TLI $>0,95$ i SRSM $<0,05$ korištene su kao indikatori dobrog pristajanja modela (Hu i Bentler 1999). U prvom koraku dozvoljene su veze među svim varijablama u modelu, a zatim su postupkom rezanja modela (eng. model trimming) uklanjane neznačajne veze te je provjeravana razlika u pristajanju, korištenjem SatorraBentler testa razlike skaliranih hi-kvadrata. U slučaju neznačajnog pada u pristajanju, parsimoničniji model iz drugog koraka zadržan je kao konačni. Analize su provedene u programu Mplus 7 (Muthén i Muthén, 1998-2015).

\section{REZULTATI}

U Tablici 1 prikazani su deskriptivni podaci za sve varijable u istraživanju, uključujući rezultate t-testova kojima su ispitane razlike između djevojčica i dječaka na svim varijablama. Na prediktorskim varijablama uglavnom nisu utvrđene statistički značajne razlike. Djevojčice i dječaci postigli su podjednak rezultat na Testu spremnosti za školu u cjelini i na pojedinim subtestovima, s visokom prosječnom rješivosti od $72,1 \%$ do $88,9 \%$ na pojedinim testovima, odnosno $79,2 \%$ za test u cjelini. Roditeljske procjene socijalno-emocionalne kompetencije djece također nisu ukazale na statistički značajnu razliku djevojčica i dječaka, a u prosjeku ukazuju na tipičnu razvijenost socijalno-emocionalne kompetencije djece. Na gotovo svim kriterijskim varijablama utvrđene su statistički značajne razlike između djevojčica i dječaka. Pri tome su na svim tim varijablama djevojčice po- 
IVANA HANZEC MARKOVIĆ: Rana školska prilagodba kao pokazatelj dječje dobrobiti: prediktivna važnost ...

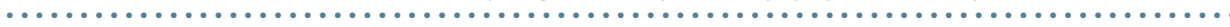

stigle bolji rezultat (na ispitu znanja iz matematike i prirode i društva te na upitniku sviđanja škole) ili su procijenjene boljima (odnosi s učiteljicama obilježeni s više bliskosti i manje konflikta, procijenjene su više uključenima i akademski kompetentnijima). Jedine kriterijske varijable na kojima nisu utvrđene statistički značajne razlike su odnosi s vršnjacima (djevojčice i dječaci procjenjuju se podjednako prihvaćenima među vršnjacima) i rezultat na ispitu znanja iz hrvatskog jezika. Općenito, ispit znanja učenici/e su riješili s visokom prosječnom rješivosti od $77,9 \%$ do $85,9 \%$.

Tablica 1. Deskriptivni podaci svih ispitivanih varijabli i rezultati testa razlika između djevojčica i dječaka

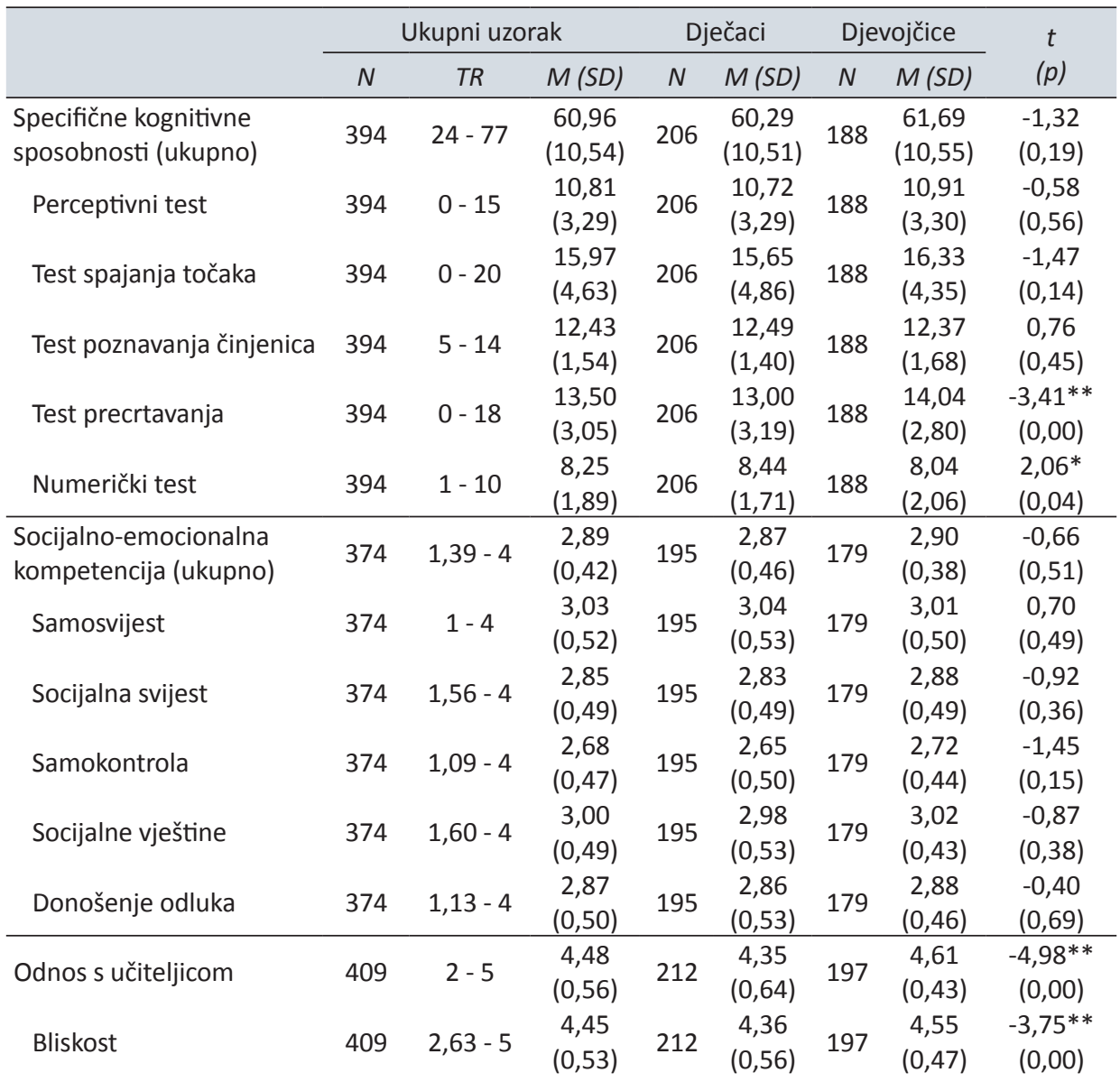




\begin{tabular}{|c|c|c|c|c|c|c|c|c|}
\hline & \multicolumn{3}{|c|}{ Ukupni uzorak } & \multicolumn{2}{|c|}{ Dječaci } & \multicolumn{2}{|c|}{ Djevojčice } & \multirow{2}{*}{$\begin{array}{c}t \\
(p)\end{array}$} \\
\hline & $N$ & $T R$ & $M(S D)$ & $N$ & $M(S D)$ & $N$ & $M(S D)$ & \\
\hline Konflikt & 409 & $1-5$ & $\begin{array}{c}1,50 \\
(0,80)\end{array}$ & 212 & $\begin{array}{c}1,67 \\
(0,91)\end{array}$ & 197 & $\begin{array}{c}1,32 \\
(0,61)\end{array}$ & $\begin{array}{l}4,64 * * \\
(0,00)\end{array}$ \\
\hline Odnos s vršnjacima & 390 & $4-16$ & $\begin{array}{l}12,85 \\
(3,00)\end{array}$ & 199 & $\begin{array}{l}12,74 \\
(3,08)\end{array}$ & 191 & $\begin{array}{l}12,96 \\
(2,92)\end{array}$ & $\begin{array}{l}-0,72 \\
(0,47)\end{array}$ \\
\hline Sviđanje škole & 390 & $0-2$ & $\begin{array}{c}1,49 \\
(0,50)\end{array}$ & 199 & $\begin{array}{c}1,36 \\
(0,57)\end{array}$ & 191 & $\begin{array}{c}1,62 \\
(0,39)\end{array}$ & $\begin{array}{c}-5,26 * * \\
(0,00)\end{array}$ \\
\hline Uključenost učenika/ica & 411 & $0,17-2$ & $\begin{array}{c}1,62 \\
(0,44)\end{array}$ & 213 & $\begin{array}{c}1,51 \\
(0,47)\end{array}$ & 198 & $\begin{array}{c}1,73 \\
(0,38)\end{array}$ & $\begin{array}{c}-5,21^{* *} \\
(0,00)\end{array}$ \\
\hline $\begin{array}{l}\text { Ispit znanja iz hrvatskog } \\
\text { jezika }\end{array}$ & 389 & $0-20$ & $\begin{array}{l}17,17 \\
(3,27)\end{array}$ & 199 & $\begin{array}{l}16,87 \\
(3,61)\end{array}$ & 190 & $\begin{array}{l}17,49 \\
(2,83)\end{array}$ & $\begin{array}{l}-1,87 \\
(0,06)\end{array}$ \\
\hline Ispit znanja iz matematike & 389 & $0-25$ & $\begin{array}{l}19,48 \\
(4,03)\end{array}$ & 199 & $\begin{array}{l}19,07 \\
(4,38)\end{array}$ & 190 & $\begin{array}{l}19,92 \\
(3,58)\end{array}$ & $\begin{array}{l}-2,10^{*} \\
(0,04)\end{array}$ \\
\hline $\begin{array}{l}\text { Ispit znanja iz prirode i } \\
\text { društva }\end{array}$ & 389 & $0-22$ & $\begin{array}{l}17,73 \\
(3,93)\end{array}$ & 199 & $\begin{array}{l}17,33 \\
(4,22)\end{array}$ & 190 & $\begin{array}{l}18,15 \\
(3,56)\end{array}$ & $\begin{array}{l}-2,07 * \\
(0,04)\end{array}$ \\
\hline Akademska kompetencija & 412 & $1-5$ & $\begin{array}{c}4,10 \\
(0,89)\end{array}$ & 213 & $\begin{array}{c}3,89 \\
(0,93)\end{array}$ & 199 & $\begin{array}{c}4,22 \\
(0,83)\end{array}$ & $\begin{array}{c}-2,82^{* *} \\
(0,01)\end{array}$ \\
\hline
\end{tabular}

Napomena: ${ }^{*} p<0,05, * * p<0,01$

Tablica 2 prikazuje korelacije svih ispitivanih varijabli. Ukupni rezultati na prediktorskim varijablama (specifične kognitivne sposobnosti i socijalno-emocionalna kompetencija) u niskoj su, ali statistički značajnoj pozitivnoj korelaciji. Različiti pokazatelji socijalne prilagodbe na školu uglavnom su međusobno značajno pozitivno povezani, no korelacije su niske do umjerene, uz zamjetnu razliku u visini korelacija ovisno o načinu mjerenja pokazatelja (dječjim samoprocjenama naspram procjenama učiteljica). Za razliku od toga, pokazatelji akademske prilagodbe u visokim su međusobnim korelacijama. Specifične kognitivne sposobnosti učenika/ica u značajnim su niskim do umjerenim pozitivnim korelacijama s gotovo svim kriterijskim varijablama, izuzev onih mjerenih dječjim samoprocjenama. S druge strane, socijalno-emocionalna kompetencija učenika/ica u značajnoj je korelaciji samo s učiteljskom procjenom kvalitete odnosa s učenicima/ cama. 


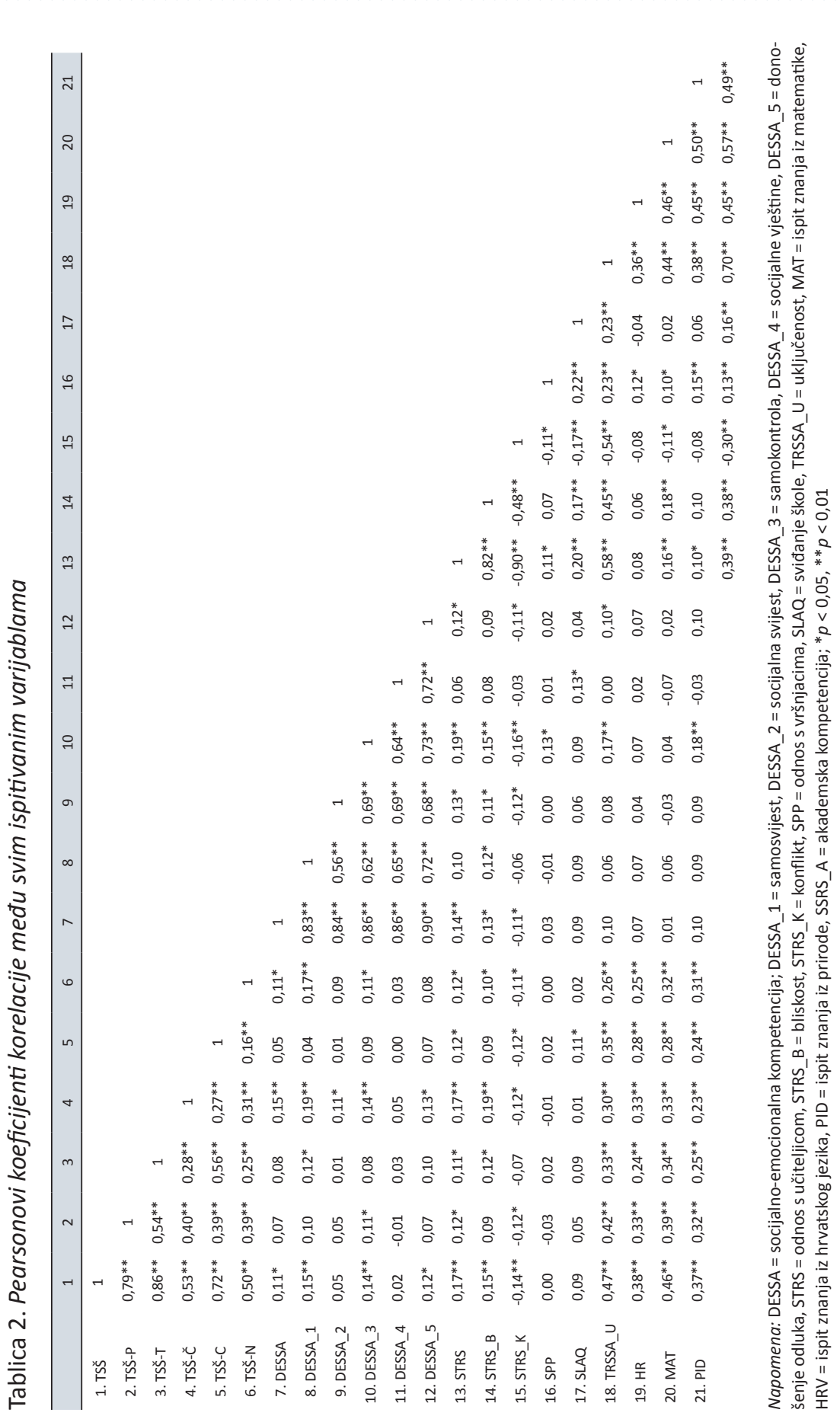


Kako bismo ispitali i usporedili prediktivnu važnost socijalno-emocionalne kompetencije i specifičnih kognitivnih sposobnosti za socijalnu i akademsku prilagodbu na školu, proveli smo strukturalno modeliranje. Mjerni model latentnog konstrukta akademske prilagodbe s četiri izmjerena pokazatelja (rezultatima učenika na ispitu znanja iz hrvatskog jezika, matematike i prirode i društva te rezultatom na Skali akademske kompetencije) pokazao je dobro pristajanje podatcima $(\chi 2 / d f=0,62, \mathrm{RMSEA}=0,00, \mathrm{CFI}=1,00, \mathrm{TLI}=1,01$, SRMR $=0,01)$, stoga je $\mathrm{u}$ tom obliku korišten $\mathrm{u}$ analizi. Za razliku od toga, pretpostavljeni mjerni model latentnog konstrukta socijalne prilagodbe s četiri izmjerena pokazatelja (odnos s učiteljicom, odnos s vršnjacima, sviđanje škole i uključenost), unatoč dobrom općem pristajanju modela $(\chi 2 / d f=1,54, \mathrm{RMSEA}=0,04, \mathrm{CFI}=0,99, \mathrm{TLI}=0,98$, SRMR $=0,02$ ) ukazao je na niske saturacije (niže od 0,30) odnosa s vršnjacima i sviđanja škole na latentnom faktoru, stoga su izmjereni pokazatelji socijalne prilagodbe korišteni kao zasebne varijable u modelu.

Početni model predikcije socijalne i akademske prilagodbe djeteta na školu na osnovu socijalno-emocionalne kompetencije i specifičnih kognitivnih sposobnosti pokazao je dobro pristajanje podatcima $\left(\chi^{2} / d f=1,91, \operatorname{RMSEA}=0,05, \mathrm{CFI}=\right.$ $0,96, \mathrm{TLI}=0,94, \mathrm{SRMR}=0,05)$, no neke veze nisu se pokazale značajnima pa su u sljedećem koraku uklonjene. Tako dobiveni model također je pokazao dobro pristajanje podatcima $\left(\chi^{2} / d f=1,89, \mathrm{RMSEA}=0,05, \mathrm{CFI}=0,95, \mathrm{TLI}=0,94, \mathrm{SRMR}=\right.$ $0,06)$, a budući da u odnosu na početni model nije došlo da statistički značajnog pada u pristajanju $(T=16,27, \Delta d f=10, p=0,09)$, parsimoničniji model zadržan je kao konačni (Slika 1$)$. 


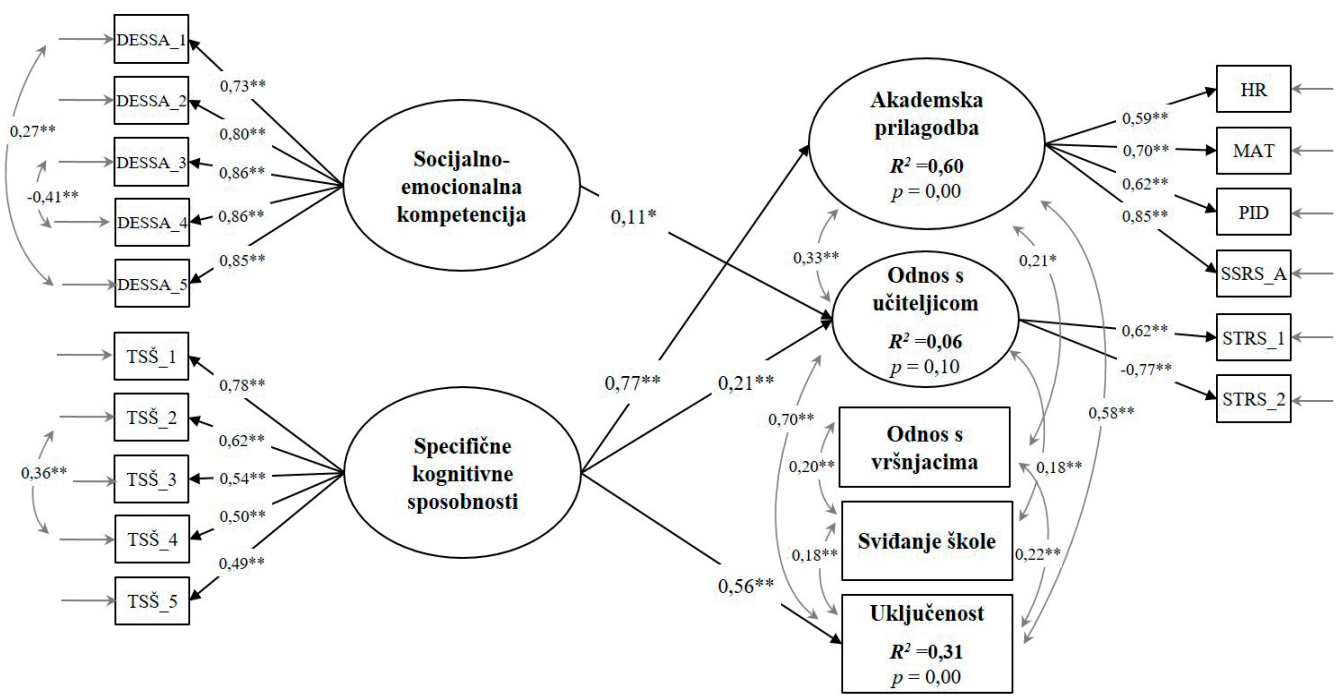

Slika 1. Završni model predikcije socijalne i akademske prilagodbe djeteta na školu na osnovu socijalno-emocionalne kompetencije i specifičnih kognitivnih sposobnosti

(Napomena: Elipse = latentne varijable; pravokutnici $=$ manifestne varijable; ${ }^{*} p<0,05,{ }^{* *} p<$ 0,$01 ; R^{2}=$ koeficijent determinacije (postotak objašnjene varijance)).

Rezultati su pokazali da specifične kognitivne sposobnosti značajno predviđaju akademsku prilagodbu, uključenost učenika/ica i odnos s učiteljicom, a socijalno-emocionalna kompetencija samo odnos s učiteljicom. Konačnim modelom objašnjeno je $60 \%$ varijance akademske prilagodbe učenika/ica na školu, dok je od četiriju pokazatelja socijalne prilagodbe na školu objašnjen značajni dio varijance samo uključenosti učenika/ica (31\% varijance).

Kako bismo provjerili moderatorsku ulogu spola u odnosu među varijablama u ovom modelu, proveli smo multigrupno testiranje pristajanja modela. Multigrupni model s uklonjenim neznačajnim vezama, uz dozvoljeno razlikovanje regresijskih koeficijenata između grupa, pokazao je dobro pristajanje podatcima $\left(\chi^{2} / d f=1,65, \mathrm{RMSEA}=0,06, \mathrm{CFI}=0,93, \mathrm{TLI}=0,92, \mathrm{SRMR}=0,09\right)$, stoga je zadržan kao početni model za daljnje testiranje moderatorskog efekta spola. U sljedećem koraku postavljeno je ograničenje jednakosti na sve značajne regresijske koeficijente. Indikatori pristajanja ukazali su na dobro pristajanje tog modela podatcima $\left(\chi^{2} / d f=1,64, \operatorname{RMSEA}=0,06, \mathrm{CFI}=0,93, \mathrm{TLI}=0,92\right.$, SRMR =0,09), a kako nije došlo do statistički značajnog pada u pristajanju u odnosu na početni model ( $T$ $=2,09, \Delta d f=3, p=0,55)$, zaključeno je da spol nema moderatorsku ulogu u od- 
nosu individualnih karakteristika djeteta (socijalno-emocionalne kompetencije i specifičnih kognitivnih sposobnosti) i socijalne i akademske prilagodbe djeteta na školu. Drugim riječima, odnosi među tim varijablama jednaki su kod djevojčica i dječaka, i sukladni onima dobivenim na ukupnom uzorku, zbog čega su u nastavku analizirani i raspravljani samo rezultati na ukupnom uzorku.

\section{RASPRAVA}

Cilj ovog istraživanja bio je ispitati i usporediti prediktivnu važnost socijalno-emocionalne kompetencije i specifičnih kognitivnih sposobnost za socijalnu i akademsku prilagodbu djeteta na školu, te ispitati moguću moderatorsku ulogu spola u odnosu ovih individualnih karakteristika djeteta i rane školske prilagodbe.

Specifične kognitivne sposobnosti, u skladu s očekivanjima, najviše su doprinijele objašnjenju akademske prilagodbe. Osim toga, djecu koja su postigla bolji rezultat na testu specifičnih kognitivnih sposobnosti na početku školske godine učiteljice su procijenile više uključenom, zainteresiranijom i suradljivijom u razredu, te su svoj odnos s tom djecom procijenile bliskijim, u većoj mjeri karakteriziranim toplinom i otvorenom komunikacijom.

U istraživanju Vlahović-Štetić i suradnica (1995), rezultat na istom testu specifičnih kognitivnih sposobnosti (TSŠ), primijenjenom na početku školske godine, bio je značajno povezan s učiteljskim procjenama uspješnosti učenika/ica u hrvatskom jeziku, matematici te prirodi i društvu tijekom prvog razreda, s prosječnom korelacijom od 0,42 , što je sukladno prosječnim korelacijama ovog testa $\mathrm{s}$ različitim pokazateljima akademske prilagodbe u našem istraživanju (Tablica 1 ). Slično tome, La Paro i Pianta (2000) u svojoj su meta-analizi dobili veličinu učinka od 0,51 za predikciju akademskih ishoda u početnim razredima na temelju kognitivnih mjera spremnosti za školu. Rana akademska kompetencija (kognitivne i pred-akademske vještine prije polaska u školu) pokazala se najboljim prediktorom akademskog uspjeha na kraju prvog razreda i u šest velikih longitudinalnih istraživanja čiji su pregled i meta-analizu napravili Duncan i suradnici (2007). Kao objašnjenje autori navode da je postizanje akademskog uspjeha kumulativan proces koji uključuje svladavanje novih, ali i poboljšanje postojećih vještina, te je zato rana akademska kompetencija učenika/ica, odnosno raspolaganje predakademskim vještinama koje se najčešće mjere testovima kognitivne spremnosti za školu, važan temelj za stjecanje novih, sve složenijih akademskih vještina tijekom školovanja (Duncan i sur., 2007).

Odnos ranih kognitivnih i pred-akademskih sposobnosti i vještina s različitim pokazateljima socijalne prilagodbe učenika/ica u dosadašnjim istraživanjima 
IVANA HANZEC MARKOVIĆ: Rana školska prilagodba kao pokazatelj dječje dobrobiti: prediktivna važnost ...

je puno manje ispitivan. Međutim, rezultati našeg istraživanja sukladni su postojećim nalazima prema kojima su specifične kognitivne i/ili pred-akademske vještine značajno povezane s većom uključenošću učenika/ica u razredne aktivnosti (npr. Archambault, Pagani i Fitzpatrick, 2013; Bossaert i sur., 2011; Ladd i sur., 1999) i boljom kvalitetom odnosa kojeg formiraju sa svojim učiteljima/cama (Archambault i sur., 2013; Nurmi, 2012). Nurmi (2012) kao moguće objašnjenje navodi Pigmalionov efekt, odnosno da učitelji/ce, znajući sposobnosti djece, iskazuju više pažnje i pozitivnih emocija u interakciji s djecom za koju očekuju da će uspjeti nego s djecom od koje očekuju slabiji uspjeh u učenju. S druge strane, predikcija veće uključenosti učenika/ica u razredne aktivnosti tijekom školske godine onih učenika/ica koji su postigli bolji rezultat na testu specifičnih kognitivnih sposobnosti na početku godine može se objasniti motivacijskim teorijama poput teorija očekivanja. Prema tim teorijama, ponašanje učenika/ica vođeno je njihovim vlastitim očekivanjem buduće uspješnosti i motivacijom za postignućem, koja je veća ukoliko dijete ima iskustvo uspjeha u prethodnim zadacima i vjeruje da može uspjeti na zadacima s kojima se suočava (Vizek Vidović, Rijavec, Vlahović Štetić i Miljković, 2014).

Suprotno očekivanjima, socijalno-emocionalna kompetencija učenika/ica, mjerena roditeljskim procjenama dječjeg poznavanja vlastitih snaga i ograničenja, kapaciteta za suradnju u socijalnim situacijama, uspješnosti kontroliranja vlastitih emocija i ponašanja, socijalno prihvatljivog ponašanja, rješavanja problema i prihvaćanja odgovornosti, nije se pokazala značajnim prediktorom akademske prilagodbe na školu, ali ni većine pokazatelja socijalne prilagodbe na školu. Očekivali smo da će djeca koja u većoj mjeri posjeduju navedene vještine lakše formirati pozitivne odnose s učiteljicom i vršnjacima, kao i da će im posjedovanje tih vještina omogućiti lakše snalaženje u novoj okolini i stoga njenu pozitivniju percepciju, lakše uključivanje u aktivnosti učenja i usvajanje školskog gradiva. Međutim, jedina značajna regresijska veza utvrđena je za odnos s učiteljicom, pri čemu je veća socijalno-emocionalna kompetencija djeteta na početku školske godine predviđala njegov/njezin bolji odnos s učiteljicom tijekom prvog razreda.

Dosadašnja istraživanja odnosa dječje socijalno-emocionalne kompetencije i školske prilagodbe i uspjeha usmjerila su se na različite aspekte socijalnoemocionalne kompetencije. Neke od njih, npr. samoregulacija, socijalne vještine, razumijevanje i znanje o emocijama, pokazale su se prediktivnim za kvalitetu odnosa koji djeca formiraju sa svojim učiteljima/cama i vršnjacima (npr. Bowes i sur., 2009; Graziano i sur., 2007; Ladd i sur., 1999; Silva i sur., 2011; Trentacosta i Izard, 2007), ili pak za akademsku prilagodbu učenika/ica (Garner i Waajid, 2008; 
Graziano i sur., 2007; Trentacosta i Izard, 2007). No, meta-analiza Duncana i suradnika (2007) pokazala je da različite mjere ranih socijalno-emocionalnih vještina i ponašanja uglavnom nisu značajni prediktori kasnijeg akademskog uspjeha, dok je u meta-analizi La Paro i Piante (2000) na osnovu mjera socijalno-emocionalnog razvoja bilo moguće objasniti u prosjeku tek $10 \%$ varijabiliteta socijalnih školskih ishoda.

Razloge neznačajnosti socijalno-emocionalne kompetencije kao prediktora u našem istraživanju možda treba tražiti u razlikama između sposobnosti i vještina iz domene socijalno-emocionalne kompetencije za koje roditelji procjenjuju da ih njihova djeca posjeduju i stvarnog ponašanja djece u razredu. Naime, moguće je da djeca posjeduju te vještine, ali ih u novom školskom kontekstu ne pokazuju u dovoljnoj mjeri da bi se, primjerice, više svidjela drugoj djeci i stekla veći broj prijatelja. Ladd i suradnici (Birch i Ladd, 1996; Ladd, 2003; Ladd i sur., 1999) naglašavaju da su upravo ponašanja učenika/ica u razredu i u školi važna za vršnjačko prihvaćanje ili odbacivanje, kao i za formiranje odnosa s učiteljem/ icom, odnosno da je stil ponašanja u razredu ono što dijete dovodi u priliku da se uključi u razredne aktivnosti. Osim toga, odstupanje rezultata od očekivanja može proizlaziti i iz toga što je naše istraživanje bilo usmjereno na odnos latentnog konstrukta socijalno-emocionalne kompetencije i različitih pokazatelja prilagodbe na školu, bez specificiranja pojedinih aspekata tog latentnog konstrukta koji su pojedinačno ispitivani u dosadašnjim istraživanjima, a koji bi mogli biti osobito relevantni za pojedine pokazatelje rane dječje školske prilagodbe. Na taj je način njihova pojedinačna važnost ostala zamaskirana.

Za odnos s učiteljicom, unatoč značajnim regresijskim koeficijentima oba prediktora (socijalno-emocionalne kompetencije i specifičnih kognitivnih sposobnosti), nije objašnjen značajan postotak varijance. Ovaj rezultat pokazuje kako, unatoč povezanosti ovih individualnih karakteristika djeteta s kvalitetom odnosa koji dijete formira s učiteljicom, predviđanje odnosa s učiteljicom na temelju socijalno-emocionalne kompetencije i specifičnih kognitivnih sposobnosti djeteta izmjerenih na početku školske godine nije pouzdano. Za razvoj bliskog odnosa s učiteljicom očito su važnije neke druge varijable koje ovim istraživanjem nisu obuhvaćene, poput već spomenutog ponašanja djece u razredu ili pak karakteristika samih učiteljica (npr. obrazovanja, iskustva, osobina ličnosti ili socijalno-emocionalne kompetencije učiteljica) (Nurmi, 2012).

Neznačajnost predikcije preostalih dvaju pokazatelja socijalne prilagodbe odnosa s vršnjacima i sviđanja škole - može proizlaziti iz metodoloških specifičnosti vezanih uz operacionalizaciju ovih varijabli u našem istraživanju. Odnos s vršnjacima mjeren je samoprocjenama djece o tome imaju li prijatelje i koliko ih 
IVANA HANZEC MARKOVIĆ: Rana školska prilagodba kao pokazatelj dječje dobrobiti: prediktivna važnost ...

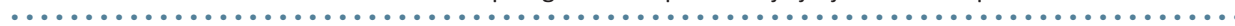

lako nalaze, koliko sami procjenjuju da se drugi vole s njima igrati i družiti, te rade li nešto češće sami ili s drugima. lako se slika o sebi formira na osnovu povratnih informacija koje djeca dobivaju iz interakcija s drugima, istraživanja pokazuju da je značajan, ali relativno mali dio varijance samoprocjene socijalne prihvaćenosti moguće objasniti sociometrijskom mjerom vršnjačke prihvaćenosti (Zafiropoulou, Sotiriou i Mitsiouli, 2007). Također, istraživanja pokazuju da su samoprocjene djece u ovoj dobi izrazito pozitivne (Harter, 1998) te često precijenjene. Procjene vršnjaka vjerojatno bi pružile realniju sliku o prihvaćenosti ili statusu pojedinog djeteta u vršnjačkoj skupini. Što se tiče sviđanja škole, pretpostavili smo da ako djeca ne posjeduju specifične kognitivne sposobnosti koje su im osnova za usvajanje školskog gradiva, škola im može biti manje zabavna, a više mjesto koje izaziva anksioznost i koje žele izbjegavati jer im je teško pratiti gradivo. Također, pretpostavili smo da ako djeca nemaju odgovarajuće socijalne i emocionalne vještine, možda su više opterećena novim socijalnim i fizičkim okruženjem u kojemu se trebaju snaći, pa se ne mogu opustiti ili uključiti u socijalne aktivnosti i aktivnosti učenja. Međutim, istraživanja pokazuju da je doprinos ranih socijalnih i emocionalnih vještina percepciji škole i uključenosti u najvećoj mjeri indirektan, i to prvenstveno preko socijalnih odnosa formiranih u razredu (Buhs i sur., 2006; Ladd i sur., 1996; Silva i sur., 2011), što u ovom radu nije ispitano.

Konačno, moguće objašnjenje odstupanja dobivenih rezultata od očekivanja o važnosti socijalno-emocionalne kompetencije i specifičnih kognitivnih sposobnosti za sve mjerene pokazatelje rane prilagodbe djece na školu proizlazi i iz činjenice da je ovo istraživanje bilo usmjereno isključivo na snage. Neki autori naglašavaju da su zapravo negativni pokazatelji socijalno-emocionalne kompetencije i nedostatak odgovarajućih (kognitivnih) sposobnosti prediktivniji za (neuspješnu) ranu prilagodbu i postizanje akademskog (ne)uspjeha (npr. Ladd i sur., 1999; Ladd i sur., 1996; Nurmi, 2012). Ovim istraživanjem ti aspekti nisu obuhvaćeni, niti instrumentima (jer su mjerili samo pozitivne pokazatelje dječje kompetencije) niti karakteristikama uzorka (koji nije u dovoljnoj mjeri obuhvatio djecu niskih (kognitivnih) sposobnosti, što je vidljivo iz deskriptivnih podataka u Tablici 1.

Što se tiče razlika između djevojčica i dječaka, utvrđeni nalaz prema kojemu su svi pokazatelji rane školske prilagodbe, osim odnosa s vršnjacima, niži na uzorku dječaka (Tablica 1), sukladan je velikom broju do sada provedenih istraživanja (npr. Betts i Rottenberg, 2007; Birch i Ladd, 1997; Bossaert i sur., 2011; Bowes i sur., 2009; Hamre i Pianta, 2001; Hughes i sur., 2008; Ladd i Dinella, 2009; Murray i Murray, 2004; Silva i sur., 2011), dok je dobiveni rezultat o nepostojanju moderatorske uloge spola sukladan nalazima meta-analize Duncana 
i suradnika (2007), koja je pokazala da je doprinos različitih pred-akademskih i socijalno-emocionalnih vještina izmjerenih pri polasku u školu podjednak za kasniji uspjeh djevojčica i dječaka.

Ovim istraživanjem obuhvaćena je šira definicija prilagodbe na školu, u terminima akademskih, ali i socijalnih pokazatelja, te je ispitana i uspoređena važnost socijalno-emocionalne kompetencije djeteta u odnosu na specifične kognitivne sposobnosti (koje su u dosadašnjim istraživanjima bile puno više zastupljene), čime su dopunjene ranije spoznaje mnogobrojnih istraživanja obrazovnih postignuća i odrednica akademskog uspjeha. Utvrdili smo da su za ranu socijalnu i akademsku školsku prilagodbu ipak važnije specifične kognitivne sposobnosti nego socijalno-emocionalna kompetencija, te da spol ne moderira odnose među ovim varijablama. Budući da direktan doprinos socijalno-emocionalne kompetencije djeteta ranoj prilagodbi, uz kontrolu kognitivnih sposobnosti, nije bio značajan, buduća istraživanja trebala bi ispitati moguće posredujuće mehanizme kojima socijalno-emocionalna kompetencija doprinosi školskoj prilagodbi.

\section{LITERATURA}

1/ AJDUKOVIĆ, M. (Ur.)(2015). Pomoć roditeljima u zaštiti dobrobiti djeteta Priručnik za socijalne radnike, druge stručnjake i suradnike centara za socijalnu skrb. Zagreb: Društvo za psihološku pomoć; Ured UNICEF-a za Hrvatsku.

2/ ALEXANDER, K. L. I ENTWISLE, D. R. (1988). „Achievement in the first 2 years of school: Patterns and processes." Monographs of the Society for Research in Child Development, 53(2, Serial No. 218).

3/ ARCHAMBAULT, I., PAGANI, L. S. I FITZPATRICK, C. (2013). „Transactional associations between classroom engagement and relations with teachers from first through fourth grade." Learning and Instruction, 23, 1-9.

4/ BABAROVIĆ, T., BURUŠIĆ, J., I ŠAKIĆ, M. (2010). "Psihosocijalne i obrazovne odrednice školskog uspjeha učenika osnovnih škola: dosezi dosadašnjih istraživanja." Suvremena psihologija, 13(2), 235-256.

5/ BURUŠIĆ, J. I ŠERIĆ, M. (2015). "Girls' and boys' achievements differences in the school context: An overview of possible explanations." Hrvatski časopis za odgoj i obrazovanje, 17(Sp. Ed. 4), 137-173.

6/ BETTS, L. R. I ROTENBERG, K. J. (2007). "A Short Form of the Teacher Rating Scale of School Adjustment." Journal of Psychoeducational Assessment, 25(2), 150-164. 
IVANA HANZEC MARKOVIĆ: Rana školska prilagodba kao pokazatelj dječje dobrobiti: prediktivna važnost ...

7/ BIRCH, S. H. I LADD, G. W. (1996). "Interpersonal relationships in the school environment and children's early school adjustment: The role of teachers and peers. U J. Juvonen i K.R. Wentzel" (Ur.), Social motivation: understanding children's school adjustment (str. 199-225). Cambridge: Cambridge University Press.

8/ BIRCH, S. H. I LADD, G. W. (1997). „The teacher-child relationship and children's early school adjustment." Journal of school psychology, 35(1), 6179.

9/ BOSSAERT, G., DOUMEN, S., BUYSE, E. I VERSCHUEREN, K. (2011). "Predicting children's academic achievement after the transition to first grade: $A$ two-year longitudinal study." Journal of Applied Developmental Psychology, 32(2), 47-57.

10/ BOWES, J., HARRISON, L., SWELLER, N., TAYLOR, A. I NEILSEN-HEWETT, C. (2009). From child care to school: Influences on children's adjustment and achievement in the year before school and the first year of school. Findings from the Child Care Choices Longitudinal Extension Study. Research Report to the NSW Department of Community Services. Sidney: Children and Families Research Centre, Macquarie University and School of Teacher Education, Charles Sturt University.

11/ DOWNER, J. T. I PIANTA, R. C. (2006). "Academic and cognitive functioning in first grade : Associations with earlier home and child care predictors and with concurrent home and classroom experiences." School Psychology Review, 35, 11-30.

12/ DUNCAN, G. J., DOWSETT, C. J., CLAESSENS, A., MAGNUSON, K., HUSTON, A. C., KLEBANOV, P., PAGANI, L. S., FEINSTEIN, L., ENGEL, M., BROOKS-GUNN, J. I SEXTON, H. (2007). "School readiness and later achievement." Developmental Psychology, 43(6), 1428-1446.

13/ GARNER, P. W. I WAAJID, B. (2008). "The associations of emotion knowledge and teacher-child relationships to preschool children's school-related developmental competence." Journal of Applied Developmental Psychology, 29(2), 89-100.

14/ GRAZIANO, P. A., REAVIS, R. D., KEANE, S. P. I CALKINS, S. D. (2007). The role of emotion regulation in children's early academic success. Journal of school psychology, 45(1), 3-19.

15/ GRESHAM, F. M. I ELLIOTT, S. N. (1990). The Social Skills Rating System. Circle Pines, MN: American Guidance Service.

16/ HAMRE, B. K. I PIANTA, R. C. (2001). „Early teacher-child relationships and the trajectory of children's school outcomes through eighth grade." Child development, 72(2), 625-638. 
17/ HARTER, S. (1985). Manual for the Self-perception profile for children. University of Denver.

18/ HARTER, S. (1998). „The development of self-representations. U W. Damon i N. Eisenberg" (Ur.), Handbook of child psychology (str. 553-617). New York: Wiley.

19/ HU, L. T. i BENTLER, P. M. (1999). „Cutoff criteria for fit indexes in covariance structure analysis: Conventional criteria versus new alternatives." Structural Equation Modeling: A Multidisciplinary Journal, 6(1), 1-55.

20/ HUGHES, J. N., LUO, W., KWOK, O. M. I LOYD, L. K. (2008). „Teacher-student support, effortful engagement, and achievement: A 3-year longitudinal study." Journal of educational psychology, 100(1), 1-14.

21/ LADD, G. (1989). „Children's social competence and social supports: Precursors of early school adjustment? U B. Schneider, G. Attili, J. Nadel i R. P. Weissberg" (Ur.), Social competence in developmental perspective (str. 277291). Dordrecht: Kluwer Academic Publishers.

22/ LADD, G. W. (2003). „Probing the adaptive significance of children's behavior and relationships in the school context: A child by environment perspective." Advances in child development and behavior, 31, 44-104.

23/ LADD, G. W. I DINELLA, L. M. (2009). „Continuity and change in early school engagement: Predictive of children's achievement trajectories from first to eighth grade?" Journal of Educational Psychology, 101(1), 190-206.

24/ LADD, G. W. I PRICE, J. M. (1987) "Predicting children's social and school adjustment following the transition from preschool to kindergarten." Child Development, 58, 1168-1189.

25/ LADD, G. W., BIRCH, S. H. I BUHS E. S. (1999). “Children's social and scholastic lives in kindergarten: Related spheres of influence?" Child Development, 70(6), 1373-1400.

26/ LADD, G. W., KOCHENDERFER, B. J. I COLEMAN, C. C. (1996). "Friendship quality as a predictor of young children's early school adjustment." Child Development, 67(3), 1103-1118.

27/ LAPARO, K. M. I PIANTA, R. C. (2000). “Predicting children's competence in the early school years: A meta-analytic review." Review of Educational Research, 70(4), 443-484.

28/ LEBUFFE, P., SHAPIRO, V. I NAGLIERI, J. (2009). The Devereux Student Strengths Assessment (DESSA). Lewisville, NC: Kaplan Press.

29/ MURRAY, C. I MURRAY, K. M. (2004). „Child level correlates of teacher-student relationships: An examination of demographic characteristics, academic orientations, and behavioral orientations." Psychology in the Schools, 41(7), 751-762. 
IVANA HANZEC MARKOVIĆ: Rana školska prilagodba kao pokazatelj dječje dobrobiti: prediktivna važnost ...

30/ MURRAY, C., WAAS, G. A. I MURRAY, K. M. (2008). „Child race and gender as moderators of the association between teacher-child relationships and school adjustment." Psychology in the Schools, 45(6), 562-578.

31/ MUTHÉN, L. K. i MUTHÉN, B. O. (1998-2015). Mplus user's guide. Seventh edition. Los Angeles, CA: Muthén \& Muthén.

32/ NURMI, J. E. (2012). „Students' characteristics and teacher-child relationships in instruction: A meta-analysis." Educational Research Review, 7(3), 177197.

33/ PATRICK, H., SUK YOON, K. I MURPHY, A. (1995). „Personality characteristics, social competence, and early school adjustment: A contextual and developmental perspective." Poster presented at the bi-annual meeting of the Society for Research in Child Development, March 1995, Indianapolis.

34/ PERRY, K. E. I WEINSTEIN, R. S. (1998). "The social context of early schooling and children's school adjustment." Educational Psychologist, 33(4), 177-194.

35/ PIANTA, R. (2001). STRS, Student-Teacher Relationship Scale. Professional manual. Lutz: Psychological Assesment Resources, Inc.

36/ RAVER, C. C. (2002). "Emotions matter: Making the case for the role of young children's emotional development for early school readiness. U L. Sherrod i J. Brooks-Gunn" (Ur.), The Society for Research in Child Development's Social Policy Report, 16(3), 3-19.

37/ RHOADES, B. L., WARREN, H. K., DOMITROVICH, C. E. I GREENBERG, M. T. (2011). "Examining the link between preschool social-emotional competence and first grade academic achievement: The role of attention skills." Early Childhood Research Quarterly, 26(2), 182-191.

38/ SILVA, K. M., SPINRAD, T. L., EISENBERG, N., SULIK, M. J., VALIENTE, C., HUERTA, S., EDWARDS, A., EGGUM, N. D., KUPFER, A. S., LONIGAN, C. J. I PHILLIPS, B. M. (2011). „Relations of children's effortful control and teacher-child relationship quality to school attitudes in a low-income sample." Early Education \& Development, 22(3), 434-460.

39/ TRAMONTANA, M. G., HOOPER, S. R. I SELZER, S. C. (1988). "Research on the preschool prediction of later academic achievement: A review." Developmental Review, 8(2), 89-146.

40/ TRENTACOSTA, C. J. I IZARD, C. E. (2007). "Kindergarten children's emotion competence as a predictor of their academic competence in first grade". Emotion, 7(1), 77-88.

41/ UNICEF (2017). Hrvatska uvodi indikatore dječje dobrobiti. <https://www. unicef.hr/vijest/hrvatska-uvodi-indikatore-djecje-dobrobiti/>. Pristupljeno 01.10.2019. 
42/ VIZEK VIDOVIĆ, V., RIJAVEC, M., VLAHOVIĆ-ŠTETIĆ, V. I MILJKOVIĆ, D. (2014). Psihologija obrazovanja. Zagreb: IEP.

43/ VLAHOVIĆ-ŠTETIĆ, V., VIZEK-VIDOVIĆ, V., ARAMBAŠIĆ, L. I MIHARIJA, Ž. (1995). Priručnik za Test spremnosti za školu. Jastrebarsko: Naklada Slap.

44/ ZAFIROPOULOU, M., SOTIRIOU, A. I MITSIOULI, V. (2007). „Relation of selfconcept in kindergarten and first grade to school adjustment." Perceptual and motor skills, 104, 1313-1327.

45/ ZINS, J., BLOODWORTH, M., WEISSBERG, R. I WALBERG, H. (2004). "The scientific base linking social and emotional learning to school success." U J. Zins, R. Weissberg, M. Wang i H. J. Walberg (Ur.), Building academic success on social and emotional learning: What does the research say? (str.1-22). New York: Teachers Press, Columbia University.

\section{SAŽETAK}

\section{RANA ŠKOLSKA PRILAGODBA KAO POKAZATELJ DJEČJE DOBROBITI: PREDIKTIVNA VAŽNOST INDIVIDUALNIH KARAKTERISTIKA DJETETA}

Polazak u osnovnu školu jedna je od glavnih razvojnih prekretnica u životu djeteta koja pred njega stavlja složen zadatak prilagodbe novim socijalnim i akademskim zahtjevima. Uspješnost udovoljavanja zahtjevima početnog školovanja povezana je s budućom prilagodbom i obrazovnim napretkom učenika, a ujedno odražava i dobrobit djeteta (njegove osjećaje i učinkovito funkcioniranje - akademsko i socijalno) u školskom kontekstu. S obzirom na važnost školske prilagodbe kao pokazatelja dječje dobrobiti, dugoročne posljedice rane prilagodbe i nekonzistentne rezultate dosadašnjih istraživanja, cilj ovog istraživanja bio je ispitati i usporediti prediktivnu važnost socijalno-emocionalne kompetencije i specifičnih kognitivnih sposobnost za socijalnu i akademsku prilagodbu djeteta na školu, te ispitati moguću moderatorsku ulogu spola u odnosu ovih individualnih karakteristika djeteta i rane školske prilagodbe. $U$ istraživanju je sudjelovalo 417 učenika/ica prvih razreda iz 12 osnovnih škola, njihovi roditelji ( $N=372)$ i učiteljice $(N=34)$. Nacrt istraživanja uključivao je prikupljanje podataka u dvije vremenske točke, na početku i na kraju školske godine, primjenom većeg broja instrumenata koje su ispunjavala djeca, roditelji i učiteljice. Podaci su obrađeni strukturalnim modeliranjem, a rezultati su pokazali da su za ranu socijalnu i akademsku prilagodbu djece na školu važnije specifične kognitivne sposobnosti nego socijalno-emocionalna kompetencija djece. Specifične kognitivne sposobnosti, u skladu s očekivanjima, bile su najbolji prediktor akademske prilagodbe, a usto 
IVANA HANZEC MARKOVIĆ: Rana školska prilagodba kao pokazatelj dječje dobrobiti: prediktivna važnost ...

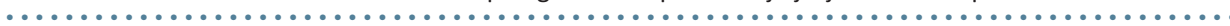

su predviđale i uključenost učenika u razredne aktivnosti i odnos s učiteljicom. Suprotno očekivanjima, socijalno-emocionalna kompetencija, na način kako je definirana i operacionalizirana u ovom istraživanju, nije predviđala niti jedan od mjerenih pokazatelja rane prilagodbe osim odnosa s učiteljicom. Obrasci odnosa među varijablama pokazali su se jednakima za djevojčice i dječake, odnosno spol nije bio značajan moderator promatranih odnosa. Ovo je istraživanje širim definiranjem prilagodbe na školu i u terminima njenih socijalnih pokazatelja, kao i utvrđivanjem relativnog doprinosa socijalno-emocionalne kompetencije djeteta (u odnosu na specifične kognitivne sposobnosti) ranoj školskoj prilagodbi, dopunilo spoznaje dosadašnjih mnogobrojnih istraživanja obrazovnih postignuća i odrednica akademskog uspjeha.

Ključne riječi: dječja dobrobit; akademska prilagodba; socijalna prilagodba; socijalno-emocionalna kompetencija; specifične kognitivne sposobnosti.

\section{SUMMARY}

\section{EARLY SCHOOL ADJUSTMENT AS A CHILD WELLBEING INDICATOR: PREDICTIVE VALIDITY OF INDIVIDUAL CHILD CHARACTERISTICS}

Transition to primary school is one of the major developmental milestones in the child's life which requires complex adjustment to new social and academic demands. Successfully meeting this early demands is associated with future adjustment and educational progress, and also reflects the wellbeing of the child (his feelings and effective functioning - academic and social) in the school context. Given the importance of school adjustment as an indicator of child wellbeing, the long-term consequences of early adjustment, and the inconsistent results of previous studies, the aim of this study was to examine and compare the predictive validity of social-emotional competence and specific cognitive skills for early social and academic school adjustment, and to examine if these relationships are moderated by the child's gender.

Participants were 417 first grade students (202 girls and 215 boys) from 12 elementary schools, their parents $(N=372)$ and teachers $(N=34)$. Research design included two waves of data collection, at the beginning and at the end of a school year, using a number of instruments filled in by children, their parents and teachers. The data were analysed using structural equation modelling, and showed that specific cognitive skills are more important for early social and academic school adjustment than children's social-emotional competence. Specific 
cognitive skills, as expected, were the best predictor of academic adjustment, and also predicted student's classroom involvement and student-teacher relationship. Contrary to expectations, social-emotional competence, in the way it was defined and operationalized in this study, did not predict any of the measured early adjustment indicators except the student-teachers relationship, with specific cognitive skills taken into account. The patterns of relationships among the variables showed to be equal for girls and boys, i.e. gender was not a significant moderator of the observed relationships. This research, by broadly defining school adjustment in terms of both its academic and social indicators, as well as by determining the relative contribution of a child's social-emotional competence (relative to specific cognitive skills) to early school adjustment, complemented the knowledge of many previous studies of educational achievement and determinants of academic success.

Key Words: child wellbeing; academic adjustment; social adjustment; social-emotional competence; specific cognitive skills. 
